\title{
Bloody diarrhoea in a patient with HIV infection
}

\author{
Mohammad Reza Ashraghi, ${ }^{1}$ Morgan Williams, ${ }^{2}$ Thillainayagam Sriram ${ }^{3}$
}

${ }^{1}$ Ashford and St Peters Hospital, Surrey, Chertsey, UK ${ }^{2}$ Medical Department, Ashford and St Peters Hospital, Surrey, Chertsey, UK

${ }^{3}$ Emergency Department, Ashford and St Peters Hospital Surrey, Chertsey, UK

\section{Correspondence to}

Dr Mohammad Reza Ashraghi, m-ashraghi@doctors.org.uk

Accepted 31 October 2015
CrossMark

To cite: Ashraghi MR, Williams M, Sriram T. BMJ Case Rep Published online: [please include Day Month Year] doi:10.1136/bcr-2015212206

\section{DESCRIPTION}

A man in his mid-40s with HIV infection-not taking highly active antiretroviral therapy (HAART) and not being monitored-with a 3-day history of profuse bloody diarrhoea and abdominal pain, presented to the emergency department. The patient believed this started after eating a take-away fish pie 2 days earlier. He was found to have an elevated $\mathrm{C}$ reactive protein of $281 \mathrm{mg} / \mathrm{L}$.

An abdominal X-ray was obtained in the emergency department (figure 1). This showed thumb printing, which represents thickening of the colonic haustral folds, and is a sign of severe submucosal oedema. The lead pipe appearance of the descending colon is caused by the complete loss of the haustral markings. These findings suggested a significant colitis, though the underlying cause could not be ascertained from X-ray alone. ${ }^{1}$

Subsequent CT of the abdomen with contrast and flexible sigmoidoscopy supported the diagnosis

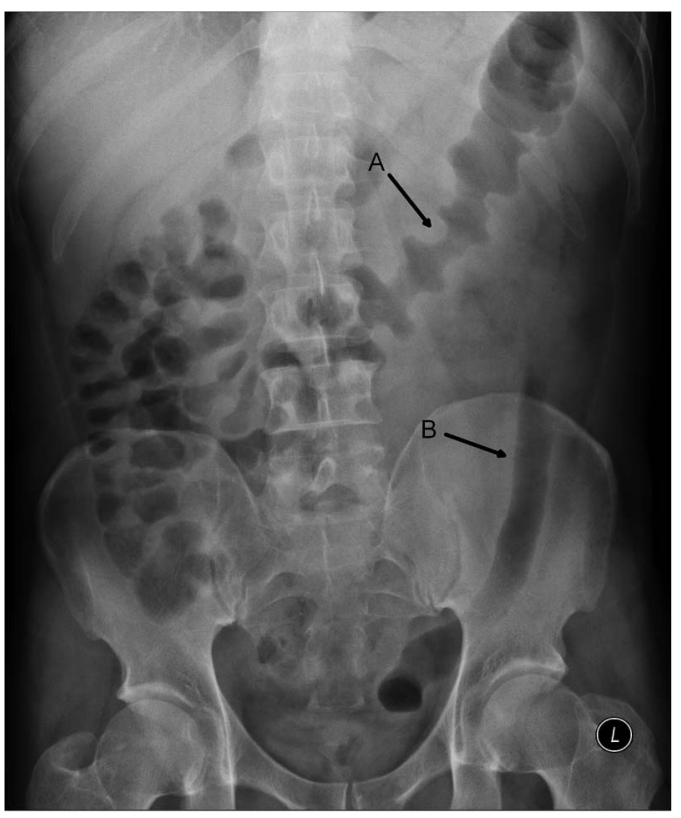

Figure 1 Abdominal X-ray taken on patient's arrival at the emergency department. There is evidence of thumb printing (A) caused by severe mucosal oedema of the transverse colon, and lead piping (B) of the descending colon, which is caused by loss of the normal colonic haustra due to oedema. These changes are typical of colitis. of colitis, and considering the patient's history, an infective cause was deemed most likely. After initial treatment with metronidazole, stool cultures grew Shigella flexneri, and the patient was successfully treated with a 14-day course of ciprofloxacin.

Shigella is a highly infectious Gram-negative bacteria, and is one of the most common causes of dysentery. Spread through the faeco-oral route, it presents with either watery diarrhoea and vomiting, or small volume bloody mucoid stools and abdominal pain. Very few organisms are required for inoculation, and onset is within $24-48 \mathrm{~h}$, with symptoms lasting around 7 days. $^{2}{ }^{3}$ The risk of Shigella has been shown to be higher in men who have sex with men and those with HIV infection. ${ }^{3}$

\section{Learning points}

Abdominal X-ray can be a valuable early diagnostic tool in patients with persistent or bloody diarrhoea.

- Infective diarrhoea should be considered in all patients with persistent or bloody diarrhoea, particularly if they are immunocompromised.

- Early stool culture is important in ensuring the correct treatment is started as soon as possible.

Contributors MRA saw the patient in the emergency department, consented him for this case report, and wrote the report. MW was responsible for the patient's care after leaving the emergency department, and reviewed and amended the case report. TS was the emergency department consultant overseeing the patient's care on admission, and also reviewed and amended the case report.

Competing interests None declared.

Patient consent Obtained.

Provenance and peer review Not commissioned; externally peer reviewed.

\section{REFERENCES}

1 James B, Kelly B. The abdominal radiograph. Ulster Med J 2013;82:179-87

2 Centers for Disease Control. Shigella-shigellosis. [ONLINE]. 2015. http://www.cdc.gov/shigella/general-information.html (accessed 25 Sep 2015).

3 Aragon TJ, Vugia DJ, Shallow S, et al. Case-control study of shigellosis in San Francisco: the role of sexual transmission and HIV infection. Clin Infect Dis 2007;44:327-34. 
Copyright 2015 BMJ Publishing Group. All rights reserved. For permission to reuse any of this content visit http://group.bmj.com/group/rights-licensing/permissions.

BMJ Case Report Fellows may re-use this article for personal use and teaching without any further permission.

Become a Fellow of BMJ Case Reports today and you can:

- Submit as many cases as you like

- Enjoy fast sympathetic peer review and rapid publication of accepted articles

- Access all the published articles

- Re-use any of the published material for personal use and teaching without further permission

For information on Institutional Fellowships contact consortiasales@bmjgroup.com

Visit casereports.bmj.com for more articles like this and to become a Fellow 